\title{
A Study Of Corporate Entrepreneurship And Firm Performance In The Computer Industry During Two Technological Disruptions
}

\author{
Ronald M. Rivas, (E-mail: rivasr@canisius.edu), Canisius College
}

\begin{abstract}
This study presents a model of firm performance for Corporate Entrepreneurship (CE) Entry-GrowthExit strategies categorized by focus of entrepreneurship, $C E$ domain, and $C E$ form. Over a longitudinal sample, this paper examines U.S. computer firm's CE strategies and firm performance during two technological disruptions namely the introduction of personal computers and subsequently the internet. This paper shows that computer companies had superior performance by implementing CE strategies of sustained regeneration and organizational rejuvenation during growth. In addition, best performing companies survived the internet technological disruption by implementing the CE strategy of domain redefinition. This study concludes with recommendations for future research.
\end{abstract}

\section{INTRODUCTION}

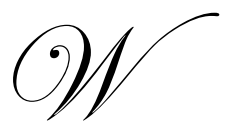

hat is the impact of corporate entrepreneurship on firm performance during technological disruptions? Both scholars and practitioners are interested in understanding corporate entrepreneurship (Chandler \& Lyon, 2001; Dess, Ireland, Zahra, Floyd, Janney, \& Lane, 2003; Gregoire, Noel, Dery, \& Bechard, 2006). Corporate entrepreneurship (CE) is the process whereby a firm creates a new organization or instigates renewal or innovation within an existing organization (Sharma \& Chrisman, 1999). Corporate Entrepreneurship has long been identified as a key means for promoting and sustaining competitive advantage (Covin \& Miles, 1999). CE is a means of accumulating, converting, and leveraging resources for competitive purpose (Floyd \& Wooldridge, 1999) to rejuvenate and redefine the firm and its markets (Covin \& Miles, 1999). CE is also a means to venture into new markets by creating new organizations from within the firm, or acquiring them, or engaging in complex alliances for the purpose of market entry (Miles \& Covin, 2002).

Although significant theorizing has been proposed to clarify the domain of CE , there is nevertheless a need to examine what is the relationship between different CE forms and firm performance (Dess, Ireland, Zahra, Floyd, Janney, \& Lane, 2003). An area that has not received much attention in CE research is the effectiveness of CE under technological disruptions. There is substantial research on CE under dynamic markets (Martin \& Eisenhardt, 2004) in particular in the computer industry (Christensen, 1997; Eisenhardt \& Tabrizi, 1995). However, the understanding of what type of CE, if any, might yield superior performance under technological disruption is limited. A technological disruption (Christensen, 1997) is a period of rapid industry transformation characterized by the introduction and adoption of new technologies resulting in the rise of new entrants and the obsolescence of incumbents (Danneels, 2004). Hence, this study contributes to the understanding of the impact of CE on firm performance during technological disruptions.

The main goal of this study is to propose a model of CE and firm performance under technological disruption. A specific objective of this study is to examine and test what types of CE yield superior performance during entry, growth and exit on an industry under technological disruption such as the computer industry. 
This study begins by briefly reviewing the CE literature and proposing the model of CE and firm performance under technological disruption. It follows a brief description of the successive technological disruptions of the computer industry from 1976 to 2007. Then it proceeds with an application of cross-section time-series regression analysis with pooled data. Tests were designed to assess the impact of CE on firm performance during entry, growth, and exit on the computer industry. It concludes with a discussion of results.

\section{THEORETICAL BACKGROUND}

Danneels (2004) defined disruptive technologies as "those technologies that render established technologies obsolete and therefore destroy the value of the investments that incumbents have made in those technologies,” (p.248). Christensen (1997) claims that overshooting is the main self-defeating mechanism of incumbents during technological disruption. On the face of disruptive technologies, incumbents tend to overshoot, that is, they offer improved versions of their products to the point where their new features are beyond the quality expectations of customers. On the other hand, new entrants will offer products often below customer quality expectations but with features that satisfy customer needs better than old products.

Figure 1

Corporate Entrepreneurship and Firm Performance during Technological Disruptions

\begin{tabular}{|c|c|c|c|c|}
\hline $\begin{array}{l}\text { Focus of } \\
\text { Entrepreneurship }\end{array}$ & CE domain & Entry & Growth & Exit \\
\hline \multirow[t]{2}{*}{ Internal } & $\begin{array}{l}\text { Corporate } \\
\text { Rejuvenation }\end{array}$ & $\begin{array}{l}\text { Innovators dilemma: } \\
\text { Incumbents } \\
\text { overshooting yields } \\
\text { diminishing } \\
\text { performance }\end{array}$ & $\begin{array}{l}\text { Corporate rejuvenation } \\
\text { yields higher } \\
\text { performance gains }\end{array}$ & $\begin{array}{l}\text { Innovators dilemma: } \\
\text { Best performers have a } \\
\text { chance of surviving } \\
\text { using Domain } \\
\text { redefinition. Other CE } \\
\text { forms lead to } \\
\text { overshooting and } \\
\text { diminishing } \\
\text { performance }\end{array}$ \\
\hline & Corporate Venturing & $\begin{array}{l}\text { Innovators dilemma: } \\
\text { Tech Disruption favors } \\
\text { performance gains } \\
\text { through Internal } \\
\text { venturing of New } \\
\text { entrants }\end{array}$ & $\begin{array}{l}\text { Uncertainty of Tech } \\
\text { disruption is resolved } \\
\text { and internal venturing } \\
\text { yields diminishing } \\
\text { performance }\end{array}$ & $\begin{array}{l}\text { Innovators dilemma: } \\
\text { Internal venturing } \\
\text { leading to domain } \\
\text { redefinition could } \\
\text { yield performance } \\
\text { gains }\end{array}$ \\
\hline \multirow[t]{2}{*}{ External } & $\begin{array}{l}\text { Corporate } \\
\text { Rejuvenation }\end{array}$ & $\begin{array}{l}\text { Innovators dilemma: } \\
\text { Incumbents emphasize } \\
\text { internal improvement } \\
\text { over domain } \\
\text { redefinition, however, } \\
\text { yielding diminishing } \\
\text { performance }\end{array}$ & $\begin{array}{l}\text { Uncertainty of Tech } \\
\text { disruption is resolved } \\
\text { and strategic } \\
\text { positioning yield } \\
\text { increasing } \\
\text { performance gains }\end{array}$ & $\begin{array}{l}\text { Innovators dilemma: } \\
\text { Incumbents exit } \\
\text { seeking to sell venture } \\
\text { to "rightful' owner } \\
\text { among new entrants to } \\
\text { overcome diminishing } \\
\text { performance }\end{array}$ \\
\hline & Corporate Venturing & $\begin{array}{l}\text { Innovators dilemma: } \\
\text { Incumbents enter } \\
\text { through acquisition to } \\
\text { overcome diminishing } \\
\text { performance of old } \\
\text { business model }\end{array}$ & $\begin{array}{l}\text { Acquisitions increase } \\
\text { market share and } \\
\text { stabilize supply chain } \\
\text { yielding performance } \\
\text { gains }\end{array}$ & $\begin{array}{l}\text { Innovators dilemma: } \\
\text { Incumbents exit } \\
\text { cutting losses by } \\
\text { divesting or liquidating }\end{array}$ \\
\hline
\end{tabular}


Covin and Miles (1999) proposed a useful typology to classify CE centered on the concept of firm level innovation with the objective of rejuvenating or purposely redefining organizations, markets or industries to create competitive advantage. According to these authors, CE could be labeled as sustained regeneration, organizational rejuvenation, strategic renewal and domain redefinition. Sustained regeneration is related to continuous improvement. Organizational rejuvenation focuses on the organizational changes necessary to improve firm processes. Strategic renewal focuses on how the firm competes, and the necessary changes to adapt to new realities of competition and competitor moves. Domain redefinition focuses on changes a firm needs to implement to enter into future new markets.

Miles and Covin (2002) clarified the domain of corporate venturing and proposed that corporate venturing differentiates by focus of entrepreneurship and presence of investment intermediation. According to these authors, corporate venturing could be internal or external to the corporation. In addition, it could be brought by direct investment in the venture through the corporations operating strategic budget or by indirect investment in the venture using financial intermediaries.

This study builds on the above mentioned typologies of CE (Covin \& Miles, 1999; Miles \& Covin, 2002) and on the call for re-examination of firm performance during disruptive technologies (Danneels, 2004). Figure 1 (See Figure 1 below) shows this study's proposed typology of CE and firm performance during technological disruptions. The model shows that firm performance is affected by the innovator's dilemma during entry and exit. An incumbent often overshoots by emphasizing on CE of "sustained regeneration" rather than switch to CE of "domain redefinition" or to corporate venturing. However, Christensen (1997) claims that companies that have become leaders through the practice of CE of "sustained regeneration" cannot enact a CE of "domain redefinition." This notion is challenged by Danneels (2004), who calls for renewed empirical theorizing and testing on this matter.

The ultimate answer to whether firms can use (or learn to use) new CE forms is empirical. Covin and Miles (1999) suggest that there is no causal relationship between one CE form and another. These authors state that "while sustained regeneration and domain redefinition, for example, may be outcomes of similar entrepreneurial processes, firms that regularly introduce new products or enter new markets (evidence of sustained regeneration) may never have an arenacreating new product-market introduction (evidence of domain redefinition), and firms that achieve the latter may not be frequent new product-market innovator" (Covin and Miles, 1999: p.55). Nevertheless, it is not clear whether firms could effectively learn different CE processes. Disruptive technologies provide the definitive ground for an empirical test of CE effectiveness. During technological disruptions, incumbents incapable of domain redefinition are rendered obsolete resulting in declining firm performance and the ultimate destruction of their investment in old technologies. Hence, other things being equal -- such as business segment, location of main operations, and timing of entry -- incumbents that implement CE of sustained regeneration/organizational rejuvenation during growth will have superior firm performance, and those that implement $\mathrm{CE}$ of domain redefinition will survive technological disruption. If there are learning across-CE forms then the former leads to the latter. Three hypotheses emerge out of the preceding discussion.

Hypothesis 1: CE of sustained regeneration / organizational rejuvenation will yield superior performance during growth.

Hypothesis 2: Best performers during growth have a chance of surviving technological disruption by implementing CE of domain redefinition.

Hypothesis 3: Other CE forms different from domain redefinition - e.g., that focuses on internal entrepreneurship --- will lead to overshooting, diminishing performance, and ultimately the collapse of the firm.

The computer industry has been widely studied for its sequential waves of rapidly changing disruptive technologies (Christensen, 1997; Eisenhardt, 1989; Eisenhardt \& Tabrizi, 1995). Figure 2 (See Figure 2 below) shows a stylized description of the sequence of disruptive technologies in the computer industry. The growth period between 1986 and 1995 is ideal to test CE effectiveness. First, it is necessary to avoid the period of turbulence that followed immediately after the occurrence of a disruptive innovation. The effect of the entrepreneur dominates the period of turbulence (Christensen, 1997), which obscures the other components of CE. 
The introduction of the personal computer in 1976 by Apple Inc. initiated the personal computer technological disruption. After a period of turbulence from 1976 to 1985, large public companies took a dominant position in the computer industry (Bergin, 2006). The period between 1985 and 1995 witnessed the rapid growth of the global computer hardware industry main competitors. The year 1995 was marked by the explosive growth of the Internet (Bergin, 2006; Newsweek, 1995). After 1996, most companies either initiated an aggressive turnaround or pressed forward on mergers and acquisitions or divestments. The shake out period of 1997 to 2000 was exacerbated by the technology-bubble-bust starting in March 2000 and lasting well into 2003 (Gregory, 2003). Technology companies were further shattered by ripple effects of corporate scandals (Times, 2006). Thus, the ideal period in the computer industry to study growth due to CE is between 1985 and 1995. This period excludes the turbulence added by entrance of new entrepreneurs to the personal computer technology (1976-1984) and to the internet technology (1996-2000) and technology corporate scandals (20002006).

Figure 2

Firm Performance Gains and Technological Disruptions in the Computer industry

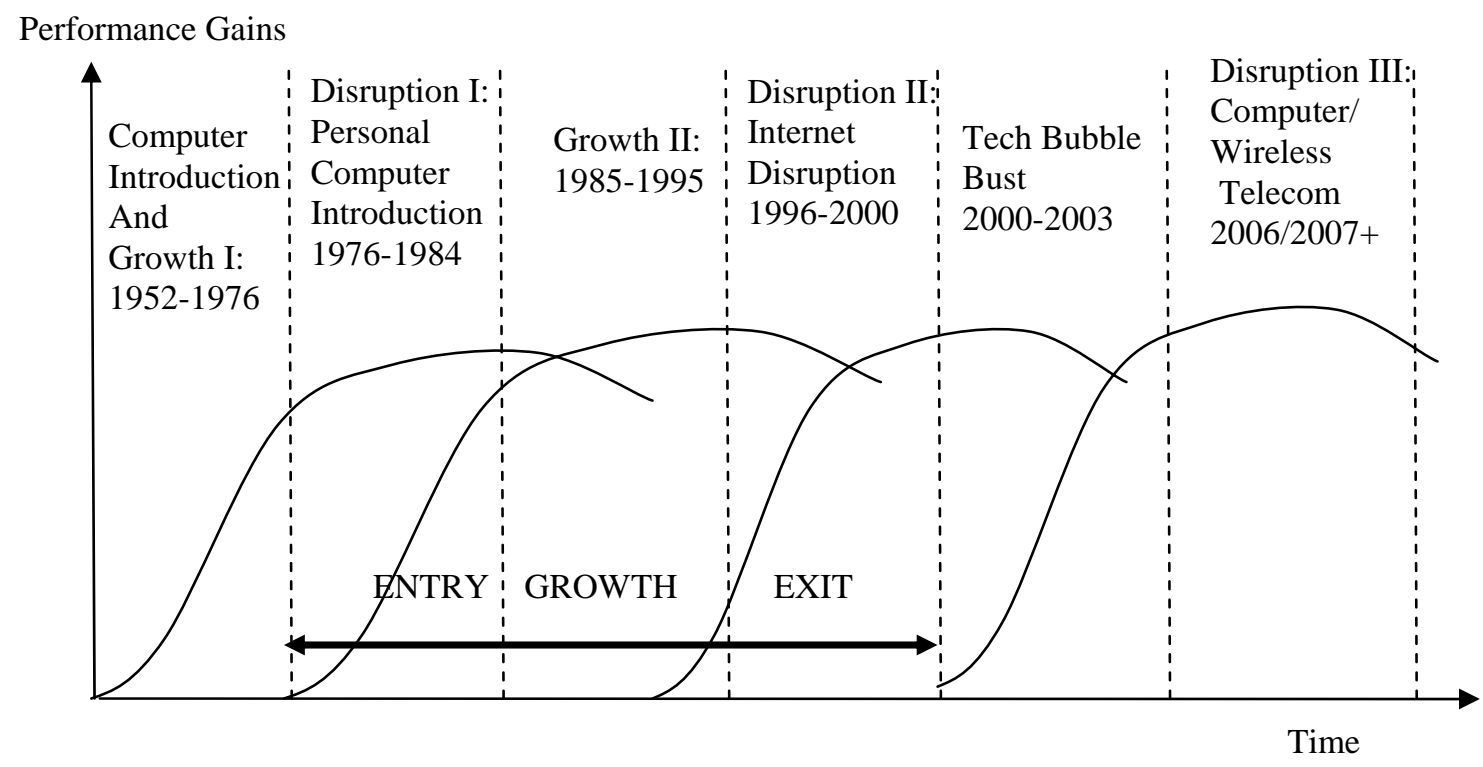

\section{METHODS}

\section{Data}

Research Insight was the main data reference. Company names obtained from Research Insight were crossreferenced with a variety of sources, including Marketguide, Hoovers, Bloomberg, and SEC filings. Ten years of data for each firm were computed to estimate a pooled cross-sectional time-series research design. Using techniques for analyzing missing data (Little \& Rubin, 1983), this study estimated R\&D missing data points for five firms resulting in a final sample of 330 firm-years of data. This study employs producer price indices for each segment from the Bureau of Labor Statistics to adjust each firm's variables to 1990 dollars. This adjustment enables cross-firm and cross-time comparisons. 
This study uses the method of structured content analysis to collect data to evaluate entry, growth, and exit strategies (Jauch, Osborn, \& Martin, 1980). This method has been applied before to analyses of the auto and airline industries (Chen \& Hambrick, 1995; Lieberman, Lau, Williams, \& Williams, 1990). A three-pronged approach was used to classify the strategies. First, a variety of sources were reviewed including company reports, firm proxy statements, electronic SEC filings, Bloomberg merger and acquisitions reports and database, and press releases. Second, the main author of this study categorized the information for each firm according to previously determined theory-driven categories. A research assistant performed similar tasks independently. Third, we compared the two sets of categories. The conflicting differences were resolved by mutually cross-referencing our categories with information from Overview and History Hoovers' profiles. This method guarantees inter-rater reliability.

\section{Sample}

The sample comprises thirty-three firms from the computer hardware industry from 1986 to 1995 . These firms compete in the U.S. personal computer, super computer, mini computer, and special computer segments of the industry. The computer industry exemplified the quintessential technological and competitive environment that makes this a highvelocity industry in which corporate entrepreneurship is critical (Bourgeois III \& Eisenhardt, 1988; Eisenhardt \& Tabrizi, 1995). The computer hardware industry is entrepreneurial per excellence, providing the ideal ground to test our model. The composition of the sample was personal computers $15 \%$, super computers $21 \%$, mini computers $30 \%$, special computers 15\% and conglomerates 18\%. The sample was divided in two geographic regions, "West" and "Rest." Two sets of companies were not included in this analysis. The first group started before 1984 but was out of business before 1995 (61 firms). These firms did not survive the personal computer technological disruption. The second group of firms started much later than 1984 and still had operations in 1995 (15 firms). These firms were in a much earlier stage of growth than those started before 1984. The remaining sample of 33 firms was active between 1984 and 1995 . Hence, the sample comprises firms that faced both the first technological disruption (personal computers) and the second one (internet).

\section{Variables}

The dependent variable is "performance gains," which is the logarithm of yearly percent changes of operating income per employee. Operating income is computed as sales at the end of the year minus the total costs-of-goods-sold, and this value divided by the number of employees. These values were adjusted using price deflators for each business segment with base US\$1990 (Lieberman \& Asaba, 1997; Lieberman \& Demeester, 1999; Lieberman, Demeester, \& Rivas, 2002).

The independent variables are "firm-fixed-effects," "past performance," "physical capital per employee gains," "R\&D per employee gains," and "cycle time reduction.” Fixed-effects are dummy variables for each firm (Greene, 1993; Judge, 1985). The firm fixed-effects in a dynamic model are performance gains due to unique characteristics of the firm. "Past Performance" is the natural logarithm of the value of two-year lagged operating income per employee. These values were adjusted using US\$ 1990 price deflators for each business segment. "Cycle time reduction" is the natural logarithm of the percent rate of change between current value of "Cycle Time" and one-year lagged value. "Cycle Time" is measured in weeks of work-in-process-inventory. These values were adjusted using US\$ 1990 price deflators for each business segment (Lieberman \& Demeester, 1999; Lieberman, Demeester, \& Rivas, 2002). Second, "R\&D per employee gains" is the natural logarithm of the percent rate of change between current values of "R\&D per employee" and one-year lagged value. "R\&D per employee" is measured as the stock of R\&D per employee. The stock of R\&D is calculated using the perpetual inventory method discounting the assets by $10 \%$ (Hulten \& Wykoff, 1996). The resulting values were adjusted to US\$ 1990 using the GDP deflator.

"PP\&E per employee gains" is the natural logarithm of the percent rate of change between current values of "PP\&E per employee" and one-year lagged value. "PP\&E per employee" is the end of the year net property-plantand-equipment per employee. These values were adjusted using US\$ 1990 price deflators for each business segment. 
There are several categorical classification variables in this study. "Acquisitions per year" is a dummy variable to measure acquisitions during growth. Firms were classified according to their mode of entry: 1) "Internal Venture," if entry is by developing a product in-house; 2) "Buy," if entry is by fully acquiring another existing firm; 3) "Alliance," if entry is established by strategic alliance or by investment in partial ownership of another existing firm. Dummy variables were used to classify firms according to their business segment, "Super Computers," "Mini computers," "Personal Computers," "Special Purpose Computers." These categories follow the practices of Eisenhardt (1990), Eisenhardt and Tabrizi (1995). There is also included a dummy variable for Conglomerate Growth, indicative of diversified firms. The exit strategies were 1) "Liquidate," if firms filed for bankruptcy and sold assets to pay debts; 2) "Divest," if firms sold computer business-units to different firms and ceased to be active in the computer industry; 3) "Sell," if firm was fully acquired by another firm; 4) "Domain redefinition," if firms divested some assets but reinvested proceeds into new business-units that were related to the disruptive technology. Figure 3 (See Figure 3 below) shows the classification of CE forms used by computer firms during the personal computer and the internet technology disruptions.

Figure 3

Corporate Entrepreneurship Forms Used by Computer Firms during Two Technological Disruptions

\begin{tabular}{|c|c|c|c|c|c|}
\hline \begin{tabular}{|l} 
Focus of \\
Entrepreneurship
\end{tabular} & CE domain & CE forms & Entry & Growth & Exit \\
\hline \multirow{6}{*}{ Internal } & \multirow{4}{*}{$\begin{array}{l}\text { Corporate } \\
\text { Rejuvenation }\end{array}$} & Sustained Regeneration & & $\begin{array}{l}\text { Investment in } \\
\text { physical capital, } \\
\text { investment in R\&D. } \\
\text { Past performance }\end{array}$ & \\
\hline & & $\begin{array}{l}\text { Organizational } \\
\text { rejuvenation }\end{array}$ & & $\begin{array}{l}\text { Cycle Time } \\
\text { reduction }\end{array}$ & \\
\hline & & Strategic Renewal & & & \\
\hline & & Domain Redefinition & & & Domain redefinition \\
\hline & \multirow{2}{*}{\begin{tabular}{|l|} 
Corporate \\
Venturing \\
\end{tabular}} & Direct-Internal & Internal venture & & \\
\hline & & Indirect-Internal & & & \\
\hline \multirow{6}{*}{ External } & \multirow{4}{*}{$\begin{array}{l}\text { Corporate } \\
\text { Rejuvenation }\end{array}$} & Sustained regeneration & & & \\
\hline & & $\begin{array}{l}\text { Organizational } \\
\text { rejuvenation }\end{array}$ & $\begin{array}{l}\text { Strategic } \\
\text { alliances }\end{array}$ & & \\
\hline & & Strategic Renewal & & & \\
\hline & & Domain Redefinition & & & \\
\hline & \multirow{2}{*}{$\begin{array}{l}\text { Corporate } \\
\text { Venturing }\end{array}$} & Direct-External & \begin{tabular}{|l|} 
Entry through \\
acquisition, \\
Entry through \\
strategic alliance
\end{tabular} & $\begin{array}{l}\text { Growth through } \\
\text { Acquisitions }\end{array}$ & \begin{tabular}{|l} 
Sell (Sell company \\
to another company), \\
Divest \\
(sell divisions to \\
different companies)
\end{tabular} \\
\hline & & Indirect-External & & & $\begin{array}{l}\text { Liquidate } \\
\text { (intermediary } \\
\text { financial institutions } \\
\text { assisting bankruptcy) }\end{array}$ \\
\hline
\end{tabular}

The study includes control variables namely "Entry before Disruption I," and location "West” and "Rest.” "Entry before Disruption I" is a dummy variable for firms that went public before 1976 --Apple Computer Inc. had IPO in 1976. The Location dummy variables classified the geographic region of main operations within the U.S.: namely "West" and "Rest." The dummy variable "West" indicates location of main operating activities in one of the western states of the U.S. namely California, Washington, and Oregon, and includes Japanese companies. "Rest" measures location of main operations in any of the continental states except the western states. Regression coefficient for regional CE effects were obtained by multiplying location dummy variables by the CE variables (Judge, 1985). 


\section{Estimation Techniques}

This study employed dynamic modeling with pooled cross-section and time-series data (Greene, 1993; Hsiao, 1986). Models were estimated with ordinary least squares OLS because the dependent variable is continuous. Regression models were estimated with an overall intercept and one less dummy variable than the total number of firms. In doing so, the dummy variable not considered in the new set of dummies becomes a benchmark. The intercept represents the individual firm-effect of the benchmark company. Each dummy variable is an estimate of the difference between each company and the benchmark company. Regression parameters' standard errors were corrected by using the Whiteconsistent variance-covariance estimates to adjust significance levels (White, 1980). Multicollinearity was tested by using the coefficient of Tolerance. The test of First and Second Moment Specification was used to test for generalized heteroscedasticity, and the Durbin-Watson test checked for autocorrelation. No instrumental variables were used to estimate the lagged variable "Past Performance." This would entail a discussion of the effect of inertia in past performance, which is beyond the scope of this paper.

\section{RESULTS}

Table 1 (See Table 1 below) shows the regression parameters for performance gains during Growth II (19851995). The model corresponding to parameters for all firms (Nation) shows that the firm fixed-effects were significant across the board $(p<0.001)$ along with "Past performance" ( $<<0.001)$, "Cycle Time reduction" $(p<0.01)$ and "PP\&E per employee gains" ( $\mathrm{p}<0.05)$. There were non-significant parameters namely "Acquisitions," "Entry before Disruption I," and "R\&D per employee gains." The model corresponding to parameters for "West" versus "Rest" firms (Regional) shows that "Cycle Time reduction" is significant for "West" firms $(\mathrm{p}<0.001)$ and not for the "Rest" firms. Conversely, "PP\&E per employee gains" is significant for the "Rest" firms $(\mathrm{p}<0.05)$ and not for the "West" firms. The F-test shows that both models are significant $(p<0.001)$, although with a low R-square $(0.17-0.18)$.

\section{Table 1}

Performance Gains due to Corporate Entrepreneurship during Growth II

\begin{tabular}{|c|c|c|c|c|c|c|}
\hline Variable & Nation & s.e. & & Regional & s.e. & \\
\hline Fixed -Effects & 0.51 & $(0.12)$ & $* * *$ & 0.51 & $(0.12)$ & $* * *$ \\
\hline Past Performance & -0.08 & $(0.02)$ & $* * *$ & -0.09 & $(0.02)$ & $* * *$ \\
\hline Acquisitions & 0.001 & $(0.04)$ & & 0.01 & $(0.04)$ & \\
\hline Entry Before Disruption I & -0.03 & $(0.03)$ & & -0.03 & $(0.03)$ & \\
\hline Cycle Time reduction: NATION & 0.11 & $(0.04)$ & $* *$ & & & \\
\hline R\&D per employee gains: NATION & 0.13 & $(0.08)$ & & & & \\
\hline PP\&E per employee gains: NATION & 0.17 & $(0.09)$ & $*$ & & & \\
\hline Cycle Time reduction: WEST & & & & 0.14 & $(0.05)$ & $* * *$ \\
\hline Cycle Time reduction: REST & & & & 0.08 & $(0.05)$ & \\
\hline R\&D per employee gains: WEST & & & & 0.24 & $(0.18)$ & \\
\hline R\&D per employee gains: REST & & & & 0.08 & $(0.10)$ & \\
\hline PP\&E per employee gains: WEST & & & & 0.13 & $(0.14)$ & \\
\hline PP\&E per employee gains: REST & & & & 0.17 & $(0.10)$ & $*$ \\
\hline$R$ square & 0.17 & & & 0.18 & & \\
\hline$F$ & 6.77 & & $* * *$ & 5.47 & & $* * *$ \\
\hline
\end{tabular}

Notes: Pooled cross-sections (33 firms) time-series (10 years) $\mathrm{N}=330$. Standard Errors are in parentheses. One-tailed tests for hypothesized effects and two-tailed otherwise.

$* \mathrm{p}<.05, * * \mathrm{p}<.01, * * * \mathrm{p}<.001$ 
Table 2 (See Table 2 below) shows performance gains during growth (firm fixed-effect) tabulated by corresponding CE strategy. The values are calculated for national, regional, entry, and exit strategies. The table reports Tstudent tests (one-tail unequal variance) between firms that chose CE of "Domain Redefinition" when facing Disruptive technology II (internet) and all other firms according to their strategies. Firms that choose "Domain Redefinition" had significant higher performance gains during growth than all other firms.

Table 2

Firm Performance during Growth and Corporate Entrepreneurship Strategies

\begin{tabular}{l|c|c|c|c|c|c|c|c|c|c}
\hline & All & \multicolumn{2}{|c|}{ Regions } & \multicolumn{2}{c|}{ Entry Strategies } & \multicolumn{4}{c}{ Exit Strategies } \\
\hline & & West & Rest & $\begin{array}{l}\text { Inter } \\
\text { Vent }\end{array}$ & Buy & $\begin{array}{l}\text { Allianc } \\
\text { e }\end{array}$ & Sell & Divest & Liquid. & $\begin{array}{l}\text { Dom. } \\
\text { Redef. }\end{array}$ \\
\hline \# of Firms & 33 & 16 & 17 & 30 & 2 & 1 & 16 & 1 & 2 & 14 \\
\hline $\begin{array}{l}\text { Performance } \\
\text { Gains during } \\
\text { Growth }\end{array}$ & $55 \%$ & $55 \%$ & $54 \%$ & $54 \%$ & $59 \%$ & $66 \%$ & $51 \%$ & $50 \%$ & $51 \%$ & $59 \% *$ \\
\hline
\end{tabular}

$* \mathrm{p}<.05$

Notes: This table reports fixed-effects parameter estimates obtained from cross-section time-series regression of CE strategies on firm performance gains using pooled data with $\mathrm{N}=330$ (33 firms, 10 years 1986-1995). These values represent the average percentage gains of firm performance during 1986-1995 tabulated for each category. Values are calculated for region, entry and exit strategies. In addition, it reports T-student tests (one-tail and unequal variance) between "Domain Redefinition" (Dom. Redef.) and all other strategies.

\section{DISCUSSION}

This study proposed a model of corporate entrepreneurship (CE) and firm performance under technological disruption. It started with the goal of testing what types of CE would yield superior performance on entry, growth and exit during two consecutive technological disruptions of the computer industry namely the personal computer and internet disruptions.

The results largely support the hypotheses that CE rejuvenation yield superior performance during growth. Firms that invested on physical capital and reduction of cycle time (evidence of sustained regeneration and organizational rejuvenation) significantly improved firm performance during growth. As expected, past performance (evidence of inertia) dampened CE effectiveness. The lack of significance of investments of R\&D on performance is disappointing, though not unexpected. Investment in R\&D is a weak measure of human capital, which ultimately should be associated with effective CE.

In addition, the results support the hypothesis that best performers during growth will have a chance of surviving technological disruption by implementing CE of domain redefinition. Firms that implemented domain redefinition to overcome technological disruption in 1996 (internet) had superior performance during the growth period 1986-1995. Hence, this evidence suggests that firms that successfully implement a form of corporate rejuvenation during growth (sustained regeneration/ organizational rejuvenation) will have a better chance to implement another corporate rejuvenation strategy, such as domain redefinition, during a disruptive technology. These findings suggest that learning of one CE form could facilitate the learning of another CE form. Given the limited sample of this study, further research is needed to test this proposition.

The findings also suggest that location is a moderator of the relationship CE-performance. Two different regions (West and Rest) show different CE profiles. The "West" had a higher prominence than the "Rest" in organizational rejuvenation through reduction in "Cycle Time." On the other hand, "Rest" firms had higher prominence than the "West" in accumulation of physical assets. These findings suggest the existence of two regional resource-based-strategies namely "innovation" (by the "West" firms) and "creative imitation" (by the "Rest" firms) (Drucker, 1985). Historical accounts (Bergin, 2006) suggest that firms in the "West" employed a strategy of 
innovation, creating a technological disruption. "West" firms were pioneers and implemented CE faster than the firms in the "Rest" by continually improving organizational processes that ultimately created manufacturing efficiency. However, firms in the rest of the US ("Rest") used a strategy of creative imitation to catch up. They were able to match the firms in the "West" by investing rapidly in physical assets, by imitating organizational processes, and by creatively replicating and adapting technological knowledge. More research is needed to assess the extent of location as moderator of CE.

\section{Limitations And Suggestions For Future Research}

Several unanswered questions from this study create opportunities for further research including issues concerning CE learning and location as moderator of the relationship CE-performance. A replication of these findings is needed on other industries that are as entrepreneurial as the computer industry.

\section{REFERENCES}

1. Bergin, T.J. 2006. From Gutenberg to the internet: A sourcebook on the history of information technology. IEEE Annals of the History of Computing, 28(2): 78-79.

2. Bergin, T.J. 2006. The origins of word processing software for personal computers: 1976-1985. IEEE Annals of the History of Computing, 28(4): 32-47.

3. Bourgeois III, L.J. \& K.M. Eisenhardt. 1988. Strategic decision process in high velocity environments: Four cases in the microcomputer industry. Management Science, 34(7): 816-35.

4. Chandler, G.N. \& D.W. Lyon. 2001. Issues of research design and construct measurement in entrepreneurship research: The past decade. Entrepreneurship: Theory \& Practice, 25(4): 101.

5. Chen, M.-J. \& D.C. Hambrick. 1995. Speed, stealth, and selective attack: How small firms differ from large firms in competitive. Academy of Management Journal, 38(2): 453-82.

6. Christensen, C.M. 1997. Innovator's dilemma: When new technologies cause great firms to fail (hardcover). Harvard Business School Press Books: 1-255.

7. Covin, J.O. \& M.P. Miles. 1999. Corporate entrepreneurship and the pursuit of competitive advantage. Entrepreneurship: Theory \& Practice, 23(3): 47-63.

8. Danneels, E. 2004. Disruptive technology reconsidered: A critique and research agenda. Journal of Product Innovation Management, 21(4): 246-58.

9. $\quad$ Dess, G.G., R.D. Ireland, S.A. Zahra, S.W. Floyd, J.J. Janney, \& P.J. Lane. 2003. Emerging issues in corporate entrepreneurship. Journal of Management, 29(3): 351-78.

10. Drucker, P.F. 1985. Entrepreneurial strategies. California Management Review, 27(2): 9-25.

11. Eisenhardt, K.M. 1989. Making fast strategic decisions in high-velocity environments. Academy of Management Journal, 32(3): 543-76.

12. Eisenhardt, K.M. \& B.N. Tabrizi. 1995. Accelerating adaptive processes: Product innovation in the global computer industry. Administrative Science Quarterly, 40(1): 84-110.

13. Floyd, S.W. \& B. Wooldridge. 1999. Knowledge creation and social networks in corporate entrepreneurship: The renewal of organizational capability. Entrepreneurship: Theory \& Practice, 23(3): 123-43.

14. Greene. 1993. Chapter 16: Models that use both cross-section and time-series data, Econometric analysis. 2nd ed. New York: Macmillan.

15. Gregoire, D.A., M.X. Noel, R. Dery, \& J.P. Bechard. 2006. Is there conceptual convergence in entrepreneurship research? A co-citation analysis of frontiers of entrepreneurship research, 1981-2004. Entrepreneurship Theory and Practice, 30(3): 333-73.

16. Gregory, M. 2003. Tech-savvy CEOs 2003: Will tech solve CEOs' governance worries? Insurance \& Technology, 28(6): 44.

17. Hsiao, C. 1986. Analysis of panel data, Cambridge university press. New York.

18. Hulten, C.R. \& F.C. Wykoff. 1996. Issues in the measurement of economic depreciation introductory remarks. Economic Inquiry, 34(1): 10-14.

19. Jauch, L.R., R.N. Osborn, \& T.N. Martin. 1980. Structured content analysis of cases: A complementary method for organizational research. Academy of Management Review, 5(4): 517-26. 
20. Judge, G.G., Griffiths, W. E., Hill, R. C., Lütkepohl, H., \& Lee, T. 1985. Inference in models that combine time series and cross-sectional data. New York: Wiley.

21. Lieberman, M.B. \& S. Asaba. 1997. Inventory reduction and productivity growth: A comparison of Japanese and us automotive sectors. Managerial \& Decision Economics, 18(2): 73-85.

22. Lieberman, M.B. \& L. Demeester. 1999. Inventory reduction and productivity growth: Linkages in the Japanese automotive industry. Management Science, 45(4): 466-85.

23. Lieberman, M.B., L. Demeester, \& R.M. Rivas. 2002. Inventory reduction in the Japanese automotive sector. MIT International Motor Vehicle Program: 1-20, Electronic Article: http://hdl.handle.net/1721.1/1638

24. Lieberman, M.B., L.J. Lau, J. Williams, \& M.D. Williams. 1990. Firm-level productivity and management influence: A comparison of American and Japanese automobile producers. Management Science, 36(10): 1193-215.

25. Little, R.J.A. \& D.B. Rubin. 1983. On jointly estimating parameters and missing data by maximizing the complete-data likelihood. American Statistician, 37(3): 218-20.

26. Martin, J.A. \& K.M. Eisenhardt. 2004. Coping with decline in dynamic markets: Corporate entrepreneurship and the recombinative organizational form, Business strategy over the industry life cycle.

27. Miles, M.P. \& J.G. Covin. 2002. Exploring the practice of corporate venturing: Some common forms and their organizational implications. Entrepreneurship: Theory \& Practice, 26(3): 21-40.

28. Newsweek. 1995. The year of the internet, Newsweek: Newsweek.

29. Sharma, P. \& J.J. Chrisman. 1999. Toward a reconciliation of the definitional issues in the field of corporate entrepreneurship. Entrepreneurship: Theory \& Practice, 23(3): 11-27.

30. Times, L.A. 2006. Editorials: The Saturday page / fallen icons; low-brow high-tech, Los Angeles Times.

31. White, H. 1980. A heteroscedasticity-consistency covariance matrix estimator and a direct test for heteroscedasticity. Econometrica, 48: 817-38. 